
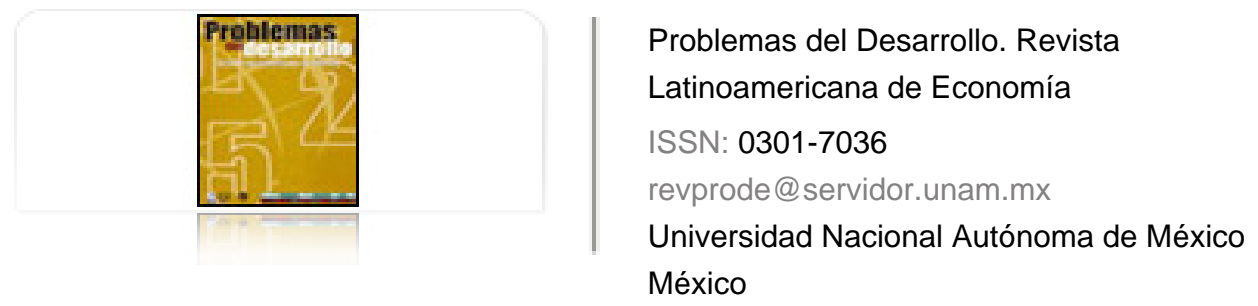

Palacios Manzano, Mercedes; Martínez Conesa, Isabel; Marín Hernández, Salvador A Comparative International Analysis of the Impact of Accounting Standards on Fundamental Accounting Variables: the USA versus Latin America

Problemas del Desarrollo. Revista Latinoamericana de Economía, vol. 38, núm. 149, abril-junio, 2007, pp. 137-157

Universidad Nacional Autónoma de México

Distrito Federal, México 


\section{A Comparative International Analysis of the Impact of Accounting Standards on Fundamental

\author{
Accounting Variables: the usa versus Latin America
}

\section{Mercedes Palacios Manzano* Isabel Martínez Conesa* Salvador Marín Hernández*}

Fecha de recepción: 1 de junio de 2006. Fecha de aceptación: 2 de febrero de 2007.

\section{Abstract}

This article examines the comparability between Latin American Generally Accepted Accounting Principles (GAAP) and us by studying 314 of the 20-F Forms reported by Latin American companies listed on the New York Stock Exchange during the period 1997-2001. The influence of us accounting in Latin America is evident in several areas. Nevertheless, the Latin American accounting model addresses special issues, such as inflation accounting, in a manner different from that of the Us The purpose of this research is to identify the impact of the international accounting differences on the fundamental accounting variables and to assess the frequency and materiality of these differences in four Latin American countries, namely Argentine, Brazil, Chile and Mexico. The results indicate that the gap between Latin American GAAP and US GAAP has not narrowed during the period.

Key words: developing countries, comparability, US GAAP reconciliation, Form 20-F

* University of Murcia, Department of Accounting and Finance, Faculty of Economics and Business, Campus de Espinardo. E mail: palacios@um.es, isama@um.es, salvlau@um.es 


\section{Resumen}

Al emplear un modelo Logit de elección múltiple ordenado y modelos de ecuaciones estructurales, se encuentra una clara relación entre educación y pobreza; los estructurales revelan la retroalimentación entre ambas variables. Producto de esta última observación, se plantea que aunque la inversión en capital humano mediante la educación es un factor clave para mejorar el ingreso de las personas, ésta por sí sola no es suficiente para alterar el cambio de condición de pobre a no pobre, pues dado que se requiere un ambiente macroeconómico favorable en el cual individuos pobres educados en el mercado de trabajo incrementen su flujo de ingresos.

Palabras claves: pobreza, educación, crecimiento económico, modelos estructurales, modelos Logit de elección múltiple.

\section{Résumé}

Dans cet article, il est procédé à l'analyse de la comparabilité existante entre les règles comptables généralement admises en Amérique latine et celles qui le sont aux ÉtatsUnis (US GAAP), à partir de l'étude de 314 rapports 20-F émis par des entreprises latino-américaines cotées à la bourse de New York durant la période 1997-2001. L'influence des règles comptables des États-Unis en Amérique latine est évidente. Néanmoins, le système comptable latino-américain a des particularités propres, telles que l'inflation, qui le différencie du modèle états-unien. L'objectif de cette recherche est d'analyser l'impact des différences comptables entre nations sur les variables comptables fondamentales, et d'évaluer la fréquence et la matérialité de ces différences pour quatre pays latino-américains: l'Argentine, le Brésil, le Chili et le Mexique. les résultats montrent que les différences entre les règles comptables latino-américaines et états-uniennes n'ont pas été réduites durant la période étudiée.

\section{Resumo}

Neste artigo se analisa a comparabilidade existente entre os princípios contábeis geralmente aceitos Latino-americanos e os Americanos (US GAAP), através do estudo de 314 Relatórios 20-F emitidos por empresas latino-americanas cotizadas na Bolsa de Nova York durante o período 1997-2001. A influência dos princípios contábeis americanos na América Latina é evidente. Não obstante, o sistema contábil Latinoamericano possui algumas particularidades, tais como a inflação, que o diferencia do modelo americano. O objetivo desta investigação é analisar o impacto das diferenças contábeis internacionais nas variáveis contábeis fundamentais, e valorizar a freqüência e materialidade destas diferenças em quatro paises Latino-americanos: Argentina, Brasil, Chile y México. Os resultados mostram que as diferenças entre os principios contábeis latino-americanos e americanos não se reduziram durante o perído de estudo. 


\section{Introduction}

Te growing internationalization of equity markets has highlighted the need to take account of international accounting differences, especially regarding the comparative analysis of fundamental accounting variables in the context of company assessment.

To achieve comparability between financial statements prepared in different countries under different regulations, the Securities and Exchange Commission (SEC) requires that foreign issuers must either use us Generally Accepted Accounting Principles (US GAAP) or present reconciliations of net income and shareholders' equity for the differences between us and local GAAP as part of a Form 20-F filing. There has been extensive coverage in the popular press discussing the necessity for non-Us companies to reconcile their financial statements with Us GAPP in order to be listed on a us securities exchange (for example Siconolfi and Salwen, 1992). The SEC and the New York Stock Exchange (NYSE) have on occasions taken opposite sides. The NYSE argues that SEC reporting requirements for non-Us firms leave them at a competitive disadvantage in terms of the number of foreign listings relative to foreign stock exchanges. However, the SEC contends that it must protect us investors from inadequate disclosures by foreign firms. Those in favour of the $20-\mathrm{F}$ reconciliation argue that requiring foreign companies to be subject to almost the same listing and disclosure rules as domestic companies is the best way of protecting domestic investors from misleading financial statements. Moreover, investors must be allowed access to foreign investments, thus ensuring the competitiveness of us stock exchanges. Opponents, on the other hand, argue that these regulations create a barrier to us exchanges due to the reconciliation costs borne by the foreign corporations.

In order to investigate this issue further, in this paper we examine the $20-\mathrm{F}$ reports of Latin American companies listed on the NYSE during the period 19972001. The objective of this study is to determine the degree of comparability of the financial information presented by Latin American companies in an international stock market. Based on a sample of 314 Forms 20-F, we examine the degree of harmonization and convergence between Latin American accounting and us accounting practices. We analyse the items which cause differences in fundamental 
accounting variables (net income and shareholders' equity) under both standards. We also assess the comparability that exists between Latin American and us accounting practices, the degree of convergence between accounting standards, and the frequency and material effects of adjustments on net income and shareholders' equity. The issue examined is whether firms are required to incur the cost of reconciling items which may only constitute a non-material difference between foreign and US GAAP income and equity.

We have analyzed financial statements of Latin American companies because of the proximity and economic interdependence between the United States and Latin America, mainly Mexico and Chile, resulting from the North American Free Trade Agreement (NAFTA), and Argentina and Brazil, resulting from the Economic, Accounting, and Administration MERCOSUR Integration Group (GIMCEA), and because these are in emerging markets that have experienced an important development in this period.

There is relatively little research on the accounting convergence of developing countries. Previous research analyzing the impact of accounting differences using US GAAP reconciliation has been limited to an assessment of country differences including the UK, the Netherlands, Sweden, Australia and Japan (e.g., Weetman and Gray, 1990, 1991; Weetman et al., 1998; Adams et al., 1999; Hellman, 1993; Norton, 1995; Cooke, 1993; Street et al., 2000). However, few studies on US GAAP reconciliation have included, solely or predominantly, companies from emerging countries, and since the 1990s many of them have entered the US capital market by trading their stock on the NYSE. Rueschhoff and Strupeck (1998) and Davis-Friday and Rivera (2000) are among the few studies on US GAAP reconciliation that have included companies from developing countries. The research reported in this article extends earlier research by investigating the degree of accounting harmonization of Latin American companies with us standards.

Our study may be seen as a contribution to the literature regarding accounting standards, reconciliation and accounting reportage for firms from developing countries.

The remainder of the article is organized as follows. The study begins with a discussion of the background for this research and a review of previous literature. This section is followed by the research methodology section, which includes sampling and data analysis considerations. Thereafter, the findings are presented. The closing section provides concluding comments on the implications of the study. 


\section{Background}

Research focusing on the harmonization or convergence of global accounting standards tended to study the harmonization of accounting standards in a subjective, descriptive or analytical manner (Meek and Saudagaran, 1990; Rivera, 1989; Samuels and Piper, 1985). More recently, research addressing harmonization tends to be more empirical: analyzing national accounting standards (de jure harmonization) or analyzing the accounting practices of companies (de facto harmonization) (Nobes and Parker, 1998; Tay and Parker, 1990).

Several prior studies have examined the progress of international accounting harmonization by examining whether official national accounting standards are in compliance with International Accounting Standards (de jure harmonization) (for a review of these studies see Larson and Kenny, 1999 and Street and Larson, 2004). The results indicate that national accounting standards are converging with international standards, although a number of significant differences remain to be addressed before convergence is achieved (Street and Larson, 2004). The harmonization or convergence of accounting regulations in Latin American countries has only been addressed in response to the North American Free Trade Agreement (NAFTA). The American Free Trade Agreement Committee for Cooperation on Financial Reporting Matters published the "Significant differences in GAAP in Canada, Chile, Mexico and the United States" (2002). This publication compares accounting pronouncements issued in those countries, as well as GAAP differences between those countries and the IASB.

Other studies have examined corporate financial statements to determine the degree of harmonization in accounting practices (de facto harmonization) (Meek and Saudagaran, 1990; Street et al., 1999; Street and Gray, 2002). These studies have mainly focused on the differences between a specific domestic set of accounting standards and either IAS's or US GAAP.

From a methodological perspective, several of these studies have attempted to measure accounting harmonization on the basis of indices. Most of them analyse the impact of accounting differences using US GAAP reconciliations. They use Us GAAP as a benchmark, and compare it with other GAAPs such as UK GAAP (Weetman and Gray, 1990, 1991) (Weetman et al., 1998) (Adams et al., 1999), GAAPs of other European countries (Hellman, 1993) (Goldberg and Godwin, 1992; Whittington, 2000), Australian GAAP (Norton 1995), Japanese GAAP (Cooke, 1993), Dutch GAAP (Vergoosen, 1996), and International GAAP (Street et al., 2000). There 
are others studies that use IAS as the yardstick (Adams et al., 1993) and others such as Gray (1980), who uses the standardized method of analysis and presentation of company accounts developed by the European Federation of Financial Analyst's Societies.

The comparative international accounting literature suggests that US GAAP are likely to be more conservative than those for the UK (Weetman and Gray, 1991; Weetman et al., 1998; Adams et al., 1999). The differences between UK and us GAAP have been reported as material and growing in recent years (Weetman et al., 1998). The most frequent and material adjustments have been the accounting treatment of goodwill, deferred taxes and intangible assets.

On the other hand, Hellman (1993) reports that US GAAP is more conservative than Swedish GAAP, and Norton (1995) finds that the hypothesis that US GAAP is more conservative than Australian financial reporting practice is not supported in terms of the impact on profits, but is supported in terms of the impact on shareholders' equity.

Street et al. (2000) examine US GAAP reconciliations by non-Us companies complying with IASB standards. They find that the differences between IASB and US GAAP are narrowing. They argue that IASB standards, in terms of their overall impact on net income, are sufficiently close to US GAAP to be acceptable to the SEC and IOSCO.

Two studies focus on companies from developing countries (Rueschhoff and Strupeck, 1998; Davis-Friday and Rivera, 2000). Rueschhoff and Strupeck's (1998) study finds that differences in accounting principles cause extreme variations in reported net income, shareholder's equity and equity return for some developing countries (Mexico, Argentine and Chile). They observe that local GAAP are less conservative than US GAAP. The greatest disparities occur for the Mexican firms. An adjustment for income taxes is the category they find to be used most frequently and the one that caused the greatest adjustments. Davis-Friday and Rivera (2000) study the 1995 and 1996 20-F reports filed with the SEC by Mexican firms. The results show than on average, net income measured under Mexican GAAP is about 26 per cent greater than the US GAAP measure, and Mexican GAAP equity is on average 74 per cent greater than US GAAP equity. The largest number of adjustments is for deferred taxes, compensation and intangible assets.

Finally, a number of recent capital market studies in the us have attempted to assess the value relevance of non-US GAAP information and reconciliations to US 
GAAP. The research findings suggest that non-US GAAP accounting has value relevance (Meek, 1983; Pope and Rees, 1992; Chan and Seow, 1996). However, the value relevance of the reconciliation to US GAAP is less clear with mixed results, although a stronger case can be made for shareholder's equity reconciliation compared with earnings reconciliation (Amir et al., 1993; Bandyopadhyay et al., 1994; Rees, 1995; Barth and Clinch, 1996; Fulkerson and Meek, 1998).

\section{Research design}

\section{Description of the sample}

The sample consists of Latin American companies listed on the NYSE. The database for this study was derived from Form 20-F. We decided to focus on four countries: Argentina, Brazil, Chile and Mexico, because the number of firms from the other Latin American countries were less relevant (Table 1). It may be argued that the NAFTA and the GIMCEA are responsible for listings from Chile and Mexico, and from Argentina and Brazil. Our study overcomes limitations associated with others studies by not using a matching procedure or including us firms in our sample. Each foreign firm with securities listed in the us capital markets is matched with itself.

Table 1

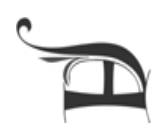

\begin{tabular}{llllll} 
& $\begin{array}{c}\text { Number of firms from developing countries listed on the NYSE } \\
\text { at the end of each year, listed by country }\end{array}$ & \\
\hline Country & 1997 & 1998 & 1999 & 2000 & 2001 \\
\hline Argentina & 9 & 9 & 9 & 10 & 10 \\
Brazil & 17 & 26 & 27 & 32 & 35 \\
Chile & 19 & 19 & 20 & 20 & 20 \\
Colombia & 1 & 1 & 1 & 1 & \\
Mexico & 17 & 19 & 21 & 22 & 24 \\
Panama & 2 & 2 & 2 & 2 & 2 \\
Peru & 3 & 3 & 3 & 3 & 3 \\
Puerto Rico & 3 & 4 & 6 & 6 & 7 \\
Venezuela & 1 & 1 & 1 & 1 & 1 \\
\hline Total & 72 & 84 & 90 & 97 & 103
\end{tabular}

A relatively large number of firms, fourteen in total (most of them Brazilian companies) used US GAAP in preparing their annual reports, thereby not needing reconciliation. Two companies used international standards to provide reconciliation with US GAAP. These companies were excluded from this study. 
The final sample contains 81 companies. The sample includes 314 20-F Forms; 31 from Argentina, 120 from Brazil, 74 from Chile and 89 from Mexico. The sample represents 77.53 per cent of the possible observations. The frequency by year and by country is shown in Table 2 .

Table 2

Frequency of the sample

\begin{tabular}{lcccccl}
\hline $20-F$ & 1997 & 1998 & 1999 & 2000 & 2001 & Total \\
\hline Argentine & 1 & 8 & 8 & 7 & 7 & 31 \\
Brazil & 14 & 25 & 27 & 27 & 27 & 120 \\
Chile & 11 & 12 & 18 & 18 & 15 & 74 \\
Mexico & 9 & 19 & 21 & 20 & 20 & 89 \\
\hline Total & 35 & 64 & 74 & 72 & 69 & 314 \\
\hline
\end{tabular}

Using Form 20-F, we have collected the following information for each company: country (Argentina, Chile, Mexico and Brazil), year of Form 20-F (from 1997 to 2001), industry (agreeing with the North American Industry Classification System), and size (measured by the variable net sale at the end of each year).

\section{Methodology}

In order to understand the significance of Latin American-us GAAP differences in practice, it is necessary to develop a methodology that will facilitate the assessment of how such differences have an impact on accounting results. Using US GAAP as the yardstick, it is possible to make an assessment of the relationship between the reported fundamental accounting variables of some countries and those same fundamental accounting variables in accordance with US GAAP.

For the purpose of making quantitative analysis of differences in accounting practice at the aggregate level, Gray (1980) developed a so-called index of conservatism. The purpose of the index is to measure the extent to which disclosed profits in one country are more or less conservative than in other countries; a particular GAAP is said to be more conservative if, on aggregate, it provides a lower net income (or shareholder's equity) level. Weetman and Gray (1990, 1991), Cooke (1993), and Street et al (2000) utilized the index in a similar manner. Weetman et 
al (1998) rename the index to focus on comparability. The index of comparability indicates the measurement impact of accounting differences.

For the purpose of this study, to compare Latin American GAAP with US GAAP, the index is calculated as follows:

NIusai $=$ Net income according to US GAAP

NIdomi $=$ Net income according to domestic GAAP

SEusai $=$ Shareholder's equity according to US GAAP

SEdomi $=$ Shareholder's equity according to domestic GAAP

ICnii =Index of comparability for net income

ICsei $=$ Index of comparability for shareholder's equity

The denominator has been taken as us fundamental accounting variables to provide a benchmark against which the Latin American fundamental accounting variables can be compared, while $20-\mathrm{F}$ reconciliations are addressed to investors that are accustomed to Us GAAP (Weetman et al., 1998). The neutral value of 1.0 is used for consistency with previous literature. An index value greater than 1 means that the Latin American net income or shareholder's equity is less conservative than the US GAAP measure would have been. An index value less than 1 indicates that the Latin American net income or shareholder's equity is more conservative than the us GAAP measure would have been. An index value exactly equal to 1 indicates neutrality in comparison with US GAAP with respect to the effect of accounting standards.

The overall index of comparability was measured and tested for each of the five years, taking each year separately in order to obtain a view of the impact on reported fundamental accounting variables on a year by year basis. We analysed the index by country, industry and size. Furthermore, the findings have been presented as distributions of adjustments in materiality bands. The index values were grouped according to measures of accounting materiality, taking the levels of 5\% and 10\% for fundamental accounting variables as rule of thumb materiality limits.

In order to test whether the Latin American reported fundamental accounting variables were significantly above or below us reported net income and shareholder's equity, the non-parametric Wilcoxon signed ranks test was applied. The Wilcoxon test is useful when the researcher is able to rank differences in order of absolute magnitude. It is based on departures from a hypothesised neutral median value of 1.0 , with no adjustment for outliers. We also use the Kruskal-Wallis test to examine 
whether there is a significant influence of year, country, industry or size on the total magnitude of the index.

Since the 20-F reconciliation contains details, it is therefore possible to establish the relative effect of individual adjustments items. The data were analysed using the survey carried out by the IASB (2001). The accounts resulting in reconciliation items were summarized into thirty categories. We distinguished between adjustments applied to net income and shareholder's equity. Table 3 reports the categories of reconciling adjustments.

Table 3

Classification of the adjustments

\begin{tabular}{|c|c|c|c|c|c|}
\hline $\operatorname{ad} 0$ & zad0 & $\begin{array}{l}\text { Restatement of prior year } \\
\text { financial statements }\end{array}$ & ad16 & zad16 & $\begin{array}{l}\text { Restructuring and } \\
\text { redundancy costs }\end{array}$ \\
\hline $\operatorname{ad} 1$ & zad1 & Taxation & ad17 & $\operatorname{zad} 17$ & Sale and lease back agreements \\
\hline $\operatorname{ad} 2$ & $\operatorname{zad} 2$ & $\begin{array}{l}\text { Pensions and other post } \\
\text { retirement benefits }\end{array}$ & ad18 & zad18 & Segmental information \\
\hline $\operatorname{ad} 3$ & zad3 & Business combinations & ad19 & zad19 & Operating expenses \\
\hline $\operatorname{ad} 4$ & $\operatorname{zad} 4$ & Goodwill & $\operatorname{ad} 20$ & $\operatorname{zad} 20$ & Revenue recognition \\
\hline $\operatorname{ad} 5$ & zad5 & Business disposals & $\operatorname{ad} 21$ & $\operatorname{zad} 21$ & Loan losses \\
\hline ad6 & zad6 & Investments & $\operatorname{ad} 22$ & $\operatorname{zad} 22$ & $\begin{array}{l}\text { Interest in long term } \\
\text { assurance business }\end{array}$ \\
\hline $\operatorname{ad} 7$ & $\operatorname{zad} 7$ & Tangible fixed assets & $\operatorname{ad} 23$ & $\operatorname{zad} 23$ & Leases \\
\hline $\operatorname{ad} 8$ & zad8 & Capitalization of interest & $\operatorname{ad} 24$ & $\operatorname{zad} 24$ & $\begin{array}{l}\text { Provisions, reserves } \\
\text { and valuation adjustments }\end{array}$ \\
\hline ad 9 & zad9 & Intangible assets & $\operatorname{ad} 25$ & $\operatorname{zad} 25$ & Inventories \\
\hline ad 10 & zad10 & $\begin{array}{l}\text { Stock based compensation } \\
\text { plans }\end{array}$ & $\operatorname{ad} 26$ & $\operatorname{zad} 26$ & Dividends \\
\hline ad 11 & zad11 & $\begin{array}{l}\text { Accounting for associates } \\
\text { and joint ventures }\end{array}$ & $\operatorname{ad} 27$ & $\operatorname{zad} 27$ & Adoption ias \\
\hline ad 12 & zad12 & Financial instruments & $\operatorname{ad} 28$ & $\operatorname{zad} 28$ & Others \\
\hline ad 13 & zad13 & $\begin{array}{l}\text { Foreign exchange } \\
\text { gains and losses }\end{array}$ & $\operatorname{ad} 29$ & $\operatorname{zad} 29$ & Depreciation \\
\hline ad 14 & zad14 & Capital instruments and debt & $\operatorname{ad} 30$ & $\operatorname{zad} 30$ & $\begin{array}{l}\text { Effects of inflation on US } \\
\text { GAAP adjustments }\end{array}$ \\
\hline ad 15 & zad15 & Minority interest & & & \\
\hline
\end{tabular}

$\operatorname{adj}=$ adjustment $\mathrm{j}$ on net income.

zadj= adjustment $\mathrm{j}$ on shareholder's equity.

After removing the most frequent adjustments, we analysed the effect of these individual adjustments by constructing partial indices, and evaluating the quantitative impact of the adjustments on US GAAP for individual items.

Where $\quad \operatorname{adij}=$ adjustment $\mathrm{j}$ on net income

zadij $=$ adjustment $\mathrm{j}$ on shareholder's equity 
ICadij $=$ Partial index by adjustment $\mathrm{j}$ on net income

ICzadij = Partial index by adjustment $\mathrm{j}$ on shareholder's equity

The interpretation of the partial index corresponds with that of the overall index of comparability. The partial index values measure the contribution of each 20-F reconciling item. The neutral value of 1 is retained for consistency. We have analysed the mean of the index by each analysed factor. We also use a test to examine whether there is a significant influence of country, industry or size on the partial index of comparability. As the distribution of the partial index is not a norm, we use the non-parametric Kruskal-Wallis test.

\section{Results}

Index of comparability

Tables 4 and 5 include median values and means of the overall index for each year and country. For calculation purposes, the outliers were excluded. The mean net income index of comparability was 1.67 . This implies that for the period 1997-2001 Latin American net income was 67 per cent higher than the same net income measured in accordance with us GAAP. Table 6 classifies all observations in terms of their level of materiality. With regard to overall income, a large proportion of the observations (64.3 per cent) were material (differences exceeding 10 per cent). However, 45.35 per cent of material observations related to a decrease in net income under US GAAP, which confirms their relevance in increasing the mean index. The reconciliations of shareholder's equity also provide significant differences. The index of comparability with respect to total equity for the period was 1.32, indicating that Latin American shareholder's equity was 32 per cent greater than the same shareholder's equity measured in accordance with US GAAP. For the whole period, again a rather large proportion of the adjustments of shareholder's equity (45.63 per cent) was material (exceeding 10 per cent).

The overall index of comparability reveals that in 1997 the adjustments to net income under Latin American accounting principles represented 24\% of net income under us GAAP (index 1.24), and by 2001 the difference had risen to $79 \%$ (index 1.79). There is an apparent indication that harmonization of measurement had moved in a negative direction over the period. Argentinean companies caused the increase in 2001. The 
Table 4

Index of comparability- net income

\begin{tabular}{lllllllllll}
\hline & \multicolumn{2}{c}{ Argentina } & \multicolumn{2}{c}{ Brazil } & \multicolumn{2}{c}{ Chile } & \multicolumn{2}{c}{ Mexico } & \multicolumn{2}{c}{ Total } \\
\hline & Mean & Median & Mean & Median & Mean & Median & Mean & Median & Mean & Median \\
1997 & 0.95 & 1.06 & 1.03 & 0.98 & 1.10 & 1.09 & 1.70 & 1.48 & 1.24 & 1.05 \\
1998 & 0.99 & 0.98 & 0.99 & 1.01 & 1.77 & 1.02 & 2.60 & 1.08 & 1.77 & 1.02 \\
1999 & 0.97 & 0.93 & 3.73 & 1.91 & 2.04 & 1.08 & 1.00 & 0.97 & 1.98 & 1.10 \\
2000 & 1.37 & 1.14 & 2.47 & 1.10 & 1.16 & 1.07 & 0.76 & 1.01 & 1.39 & 1.07 \\
2001 & 1.78 & 2.02 & 2.32 & 1.24 & 2.22 & 1.16 & 1.13 & 1.05 & 1.79 & 1.11 \\
Total & 1.26 & 1.05 & 2.14 & 1.03 & 1.69 & 1.09 & 1.42 & 1.08 & 1.67 & 1.08 \\
\hline
\end{tabular}

Table 5

Index of comparability-shareholder's equity

\begin{tabular}{ccccccccccc}
\hline & \multicolumn{1}{c}{ Argentina } & \multicolumn{2}{c}{ Brazil } & \multicolumn{2}{c}{ Chile } & \multicolumn{2}{c}{ Mexico } & Total \\
\hline & Mean & Median & Mean & Median & Mean & Median & Mean & Median & Mean & Median \\
1997 & 1.05 & 1.04 & 2.47 & 1.00 & 1.03 & 1.03 & 1.30 & 1.21 & 1.59 & 1.04 \\
1998 & 1.05 & 1.05 & 1.15 & 1.01 & 1.04 & 1.05 & 1.41 & 1.26 & 1.21 & 1.05 \\
1999 & 1.02 & 1.04 & 1.09 & 1.04 & 0.99 & 1.00 & 2.00 & 1.29 & 1.38 & 1.07 \\
2000 & 1.02 & 1.07 & 0.99 & 1.02 & 1.01 & 1.03 & 1.33 & 1.09 & 1.11 & 1.04 \\
2001 & 3.56 & 2.82 & 0.99 & 1.02 & 1.03 & 1.04 & 1.22 & 1.08 & 1.41 & 1.04 \\
Total & 1.64 & 1.07 & 1.27 & 1.01 & 1.02 & 1.03 & 1.48 & 1.19 & 1.32 & 1.04 \\
\hline
\end{tabular}

Table 6

Frequency table of distribution of values of index of comparability

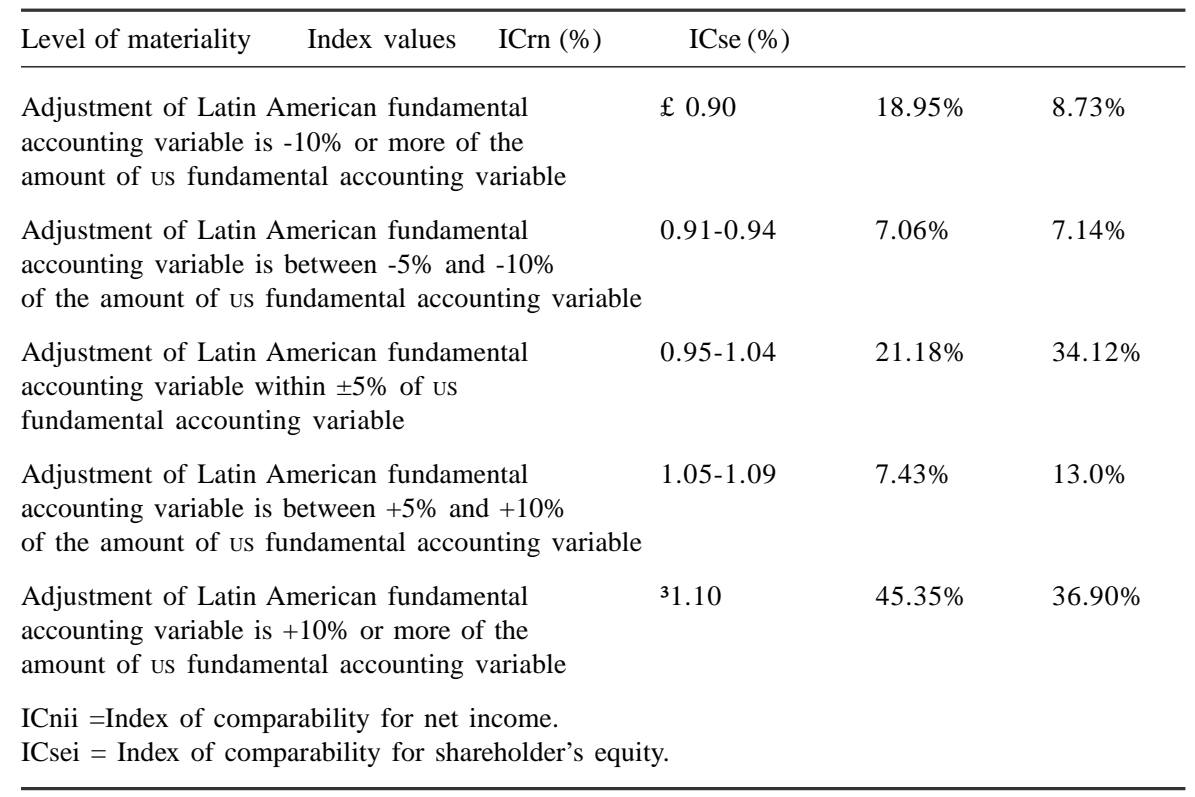


value of the index for Argentinean companies rose from 1.37 in 2000 to 1.78 in 2001. Nevertheless, the value of the index for Mexican companies levels off towards 1, meaning that there has been a harmonization process between Mexican and US GAAP. On shareholder's equity, from 1997 to 1999, a gap emerged between Latin American and usshareholders' equity, but the temporal trend was reversed during 2000 and 2001.

In reviewing the differences between countries, the maximum restatement in net income was carried out by Brazilian companies. Brazil was the least conservative country of the sample. After Brazil come Chile and Mexico, with domestic net income of $69 \%$ and $42 \%$ respectively higher than American net income. Argentinean net income was the closest to us net income. There is practical neutrality between these standards. The mean index values for the four countries were greater than the neutral value. This implies that Latin American accounting practices tend to be less conservative than US GAAP.

The results of the shareholder's equity index show that the greatest disparities occur for the Argentinean companies. After Argentina come Mexico and Brazil. Chilean shareholder's equity was closest to American shareholder's equity. Again, the value of the index was higher than 1, so American GAAP were more conservative than Latin American GAAP in the measurement of shareholder's equity.

The results for the others factors reveal that the maximum restatement of net income by industry was carried out by companies included in non-financial entity. These adjustments increased their domestic net income by more than $34 \%$ to recalculate it in line with us GAAP. The medium-sized companies were the ones that modified their domestic net income to a greater absolute extent to calculate it according to US GAAP (index 1.95). However, the maximum variation of shareholder's equity was carried out by companies included as financial entities (index 2.14), adding adjustments to the domestic figure. The largest sized companies were the ones that modified their domestic shareholder's equity to a greater absolute extent in order to calculate it according to US GAAP (index 1.51) (Table 7 and 8).

Table 7

Index of comparability by industry

\begin{tabular}{lllllllll}
\hline & \multicolumn{3}{c}{ Net Income Index } & \multicolumn{4}{c}{ Shareholder's Equity Index } \\
& Financial & \multicolumn{2}{c}{ Non-financial } & Financial & \multicolumn{4}{c}{ Non-financial } \\
\hline & Mean & Median & Mean & Median & Mean & Median & Mean & Median \\
1997 & 0.94 & 0.94 & 1.64 & 1.05 & 1.37 & 1.37 & 1.23 & 1.03 \\
1998 & 0.89 & 0.89 & 1.22 & 1.05 & 1.77 & 1.97 & 1.77 & 1.01 \\
1999 & 0.81 & 0.84 & 1.44 & 1.08 & 4.41 & 1.21 & 1.77 & 1.09 \\
2000 & 0.89 & 0.92 & 1.13 & 1.04 & 1.24 & 1.20 & 1.41 & 1.03 \\
2001 & 1.69 & 0.98 & 1.39 & 1.04 & 1.31 & 1.13 & 1.83 & 1.11 \\
Total & 1.04 & 0.90 & 1.34 & 1.05 & 2.14 & 1.16 & 1.62 & 1.07 \\
\hline
\end{tabular}


Table 8

Index of comparability by size

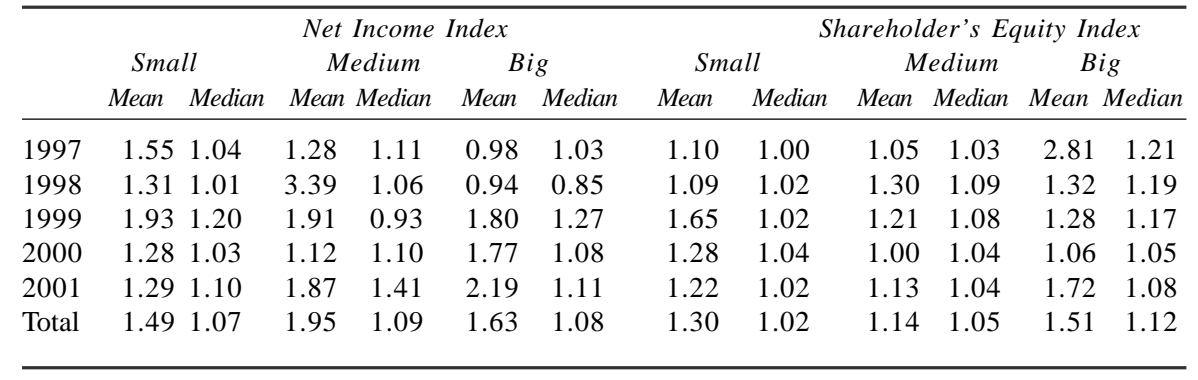

The non-parametric Wilcoxon test (Table 9) indicates that statistically significant differences between Latin American and us net income occurred in the years 1999, 2000 and 2001 (at $\mathrm{p}<0.05$ ). The range of values above and below 1.0 was such that the median values in those years were significantly different from 1.0. Moreover, the Wilcoxon test confirms the significance of Argentina's, Chile's and Mexico's results. There were also significant differences for industry, and small and mediumsized companies. The results for the shareholders' equity index confirm that the index value for all the analysed factors was significantly greater than 1 .

Table 9

Results of Wilcoxon test

\begin{tabular}{lcc}
\hline & Net incomeP value & Shareholder's equityP value \\
\hline Overall & $0.00^{*}$ & $0.00^{*}$ \\
Year & & \\
1997 & 0.12 & $0.00^{*}$ \\
1998 & 0.56 & $0.00^{*}$ \\
1999 & $0.00^{*}$ & $0.02^{*}$ \\
2000 & $0.03^{*}$ & $0.00^{*}$ \\
2001 & $0.00^{*}$ & $0.02^{*}$ \\
Country & & \\
Argentina & $0.03^{*}$ & \\
Brazil & 0.08 & $0.03^{*}$ \\
Chile & $0.00^{*}$ & $0.02^{*}$ \\
Mexico & $0.01^{*}$ & $0.00^{*}$ \\
Industry & & \\
Financial & $0.00^{*}$ & $0.00^{*}$ \\
Non-financial & $0.00^{*}$ & $0.01^{*}$ \\
Size & & \\
Small & $0.00^{*}$ & $0.00^{*}$ \\
Medium & $0.00^{*}$ & $0.00^{*}$ \\
Large & 0.06 & $0.00^{*}$ \\
\hline
\end{tabular}

* Significant at $5 \%$. 
The results from the Kruskal-Wallis test conclude that there were no statistically significant relationships between country, year, company size or industry and the quantitative variation of the domestic net income to be restated as US GAAP However, regarding the quantitative variation of domestic shareholder's equity, all the analysed factors, except year, influenced the index of comparability (Table 10).

Table 10

Results of Kruskal-Wallis test

\begin{tabular}{lcc}
\hline & $\begin{array}{l}\text { Net Income Index } \\
P \text { value }\end{array}$ & $\begin{array}{l}\text { Shareholder's Equity Index } \\
P \text { value }\end{array}$ \\
\hline Country & 0.65 & $0.00^{*}$ \\
Year & 0.19 & 0.45 \\
Industry & 0.08 & $0.00^{*}$ \\
Size & 0.97 & $0.01^{*}$ \\
\hline
\end{tabular}

* Significant at $5 \%$.

The impact of different adjustments items

Table 11 lists the top ten categories that have the highest number of reconciliation items. Table 12 shows the quantitative impact of the most frequent adjustments in the fundamental accounting variables. First of all, it is expected, due to the sample of firms from high inflation economies, that this category would cause significant adjustments. Latin American GAAP requires that financial statements recognize the effects of inflation. On the other hand, under US GAAP general price level-adjusted financial statements are not required. Nevertheless, the reconciliation to US GAAP does not include a reversal of the restatement of financial statements for the effects

Table 11

Frequency of the adjustments

\begin{tabular}{lll}
\hline Adjustments $\%$ & NetIncome & Shareholders equity \\
\hline Taxation & 78.80 & 75.63 \\
Capitalization of interest & 47.47 & 43.99 \\
Tangible fixed assets & 42.09 & 45.57 \\
Minority interest & 40.82 & 41.14 \\
Pensions and other post retirement benefits & 33.54 & 39.24 \\
Goodwill & 32.91 & 32.59 \\
Intangible assets & 32.28 & 30.06 \\
Investments & 29.11 & 24.68 \\
Provisions. Reserves and valuation adjustments & 27.53 & 23.10 \\
Others & 21.84 & 18.99 \\
\hline
\end{tabular}


of inflation. The SEC does not require Latin American firms to reconcile what may be the most significant reporting difference between the two countries, inflation accounting, because it represents a comprehensive measure of the effects of pricelevel changes in the Latin American economy and, as such, is considered a more meaningful presentation than historical cost-based financial reporting.

A review of the Latin American 20-F reconciliation reveals that aspects of the accounting treatment of deferred taxes and tangible fixed assets are the most significant component of the difference in reported net income and equity, both in frequency of occurrence (Table 11) and magnitude of adjustment (Table 12).

Table 12

Partial index of comparability

\begin{tabular}{lllll}
\hline Adjustments & ICadj & Mean & ICzadj & Mean \\
\hline Taxation & ICad1 & 1,93 & ICzad1 & 3,34 \\
Pensions & ICad2 & 0,75 & ICzad2 & 2,65 \\
Goodwill & ICad4 & 1,16 & ICzad4 & 0,99 \\
Tangible fixed assets & ICad7 & 2,64 & ICzad7 & $-1,63$ \\
Capitalization of interest & ICad8 & 0,96 & ICzad8 & 0,69 \\
Intangible assets & ICad9 & 1,03 & ICzad9 & 1,01 \\
Minority interest & ICad15 & 1,07 & ICzad15 & 0,92 \\
\hline
\end{tabular}

ICadij $=$ Partial index by the adjustment $\mathrm{j}$ on net income

ICzadij $=$ Partial index by the adjustment $j$ on shareholder's equity

The effect of adjustments for deferred taxes was a decrease in the reported Latin American income to be translated into US GAAP income. This difference was also reflected, on a cumulative basis and with the same sign, in the reconciliations to shareholder's equity reported in the 20-Fs. On average, the effect of the adjustment was such that Latin American reported net income was 93\% greater than US net income (index 1.93) and Latin American shareholder's equity was 234\% greater than shareholder's equity under US GAAP (index 3.34) (Table 12). However, the frequency and quantitative impact of this adjustment decreased during the period as consequence of the standards issued in 2000 (revised Bulletin D-4 "Accounting for Income and Asset Taxes and Employee Profit Sharing" in Mexico, and Technical Bulletin No. 6 in Chile). Prior to the effective date of these standards, deferred income taxes resulted from the partial liability method of accounting whereby only identifiable, nonrecurring temporary differences (those expected to reverse over a definitive period of time) were accounted for. Under US GAAP, deferred income tax 
is recorded under the liability method (SFAs109). Therefore, the results of efforts made to harmonize taxation must be positively valued, because the frequency and the quantitative impact of this adjustment have decreased during the period 19972001.

The results about the adjustment related to tangible fixed assets show that the proportion of companies that make this adjustment has increased over the years. Continuing through Table 12, on average, the effect of this adjustment is that Latin American reported net income was $164 \%$ greater than us net income (index 2.64) and Latin American shareholders' equity was 263\% lower than shareholders' equity under US GAAP (index -1.63). The US insistence on historical cost accounting requires the elimination of any element of depreciation based on replacement cost and of any revaluation of fixed assets. However, under Argentinean and Brazilian GAAP, the revaluation of property plant and equipment is allowed, and under Chilean GAAP, certain tangible fixed assets are reported in the financial statements at amounts determined in accordance with a technical appraisal.

Another significant item among those listed in Tables 11 and 12, in terms of both recurrence and amount, is the capitalization of interest. Under Chilean, Argentine and Mexican GAAP, the capitalization of interest is optional, whereas under Brazilian and US GAAP, the capitalization of interest is required. In the early years of capitalization net income is higher in the capitalising company and profit is lower in the write-off company. But then, as time progresses, with any one transaction, the position reverses and the write-off company looks better because there is no amortisation. Consequently, the result of this reconciliation led to an increase in the reported Latin American fundamental accounting variables to arrive at us amounts. The cumulative effect caused by this difference is also reported in Table 12.

The results obtained from the application of the Kruskal-Wallis test are shown in Table 13. The net income partial index of taxation, tangible fixed assets, intangible assets and goodwill was related to the country. Also, tangible fixed assets were related to size, and goodwill to industry. On the other hand, the firm's country determined all the shareholders' equity adjustments. The magnitude of shareholder's equity adjustments related to taxation and goodwill showed a relationship with industry, while tangible fixed assets, intangible and minority interests were related to size. There was no temporal trend in the magnitude of the adjustments; there was no relationship between year and the magnitude of the adjustments. 
Table 13

Results of kruskal-wallis test for partial index

\begin{tabular}{llllllllll}
\hline Partial Index & \multicolumn{2}{c}{ Year } & \multicolumn{4}{c}{ Country } & \multicolumn{2}{c}{ Industry } & \multicolumn{2}{c}{ Size } \\
\hline & N I & S E & N I & S E & N I & S E & N I & S E \\
Taxation & 0.30 & 0.65 & $0.00^{*}$ & $0.00^{*}$ & 0.65 & $0.00^{*}$ & 0.39 & 0.34 \\
Pensions & 0.80 & 0.43 & 0.15 & $0.03^{*}$ & 0.87 & 0.74 & 0.51 & 0.72 \\
Goodwill & 0.95 & 0.98 & $0.00^{*}$ & $0.00^{*}$ & $0.00^{*}$ & $0.00^{*}$ & 0.83 & $0.02^{*}$ \\
Tangible fixed assets & 0.14 & 0.97 & $0.00^{*}$ & $0.00^{*}$ & 0.91 & 0.73 & $0.00^{*}$ & $0.00^{*}$ \\
Capitalization interest & 0.21 & 0.15 & 0.45 & $0.00^{*}$ & 0.65 & 0.64 & 0.59 & 0.99 \\
Intangible assets & 0.85 & 0.99 & $0.00^{*}$ & $0.00^{*}$ & 0.30 & 0.79 & 0.08 & 0.02 \\
Minority interest & 0.47 & 0.45 & 0.68 & $0.00^{*}$ & 0.94 & 0.60 & 0.44 & 0.00 \\
& & & & & & & &
\end{tabular}

* Significant at $5 \%$.

\section{Summary and conclusions}

Prior works examining the differences between Latin American financial reporting practice and US GAAP suggest that the latter are more conservative. This study has attempted to assess the quantitative impact of these differences on the measurement of net income and shareholder's equity for Latin American companies reporting on Form $20-\mathrm{F}$ to the SEC.

The results from the analysis of overall differences in net income and shareholders' equity between Latin American GAAP and US GAAP indicate that Latin American practices were less conservative than US GAAP during the period, in terms of the impact on fundamental accounting variables. These results are consistent with Rueschhoff and Strupeck (1998) and Davis-Friday and Rivera (2000).

The most frequent category of reconciling items was deferred taxes, capitalization of interest and tangible fixed assets. The same results were obtained in IASB(2001). Most of the adjustments have decreased their quantitative impact during the period. The efforts made in formally harmonizing the subjects discussed such as taxation must be positively valued. However, the partial index of comparability for tangible fixed assets has steadily increased, creating the necessity to reduce their practical treatment in order to achieve the desirable harmonization.

Finally, the results indicate that the differences between Latin American and us GAAP are not significant, but did not narrow during the period 1997-2001. The temporal trend in the use of adjustments has increased over time, suggesting a decline in the comparability of the financial statements. The results confirm the concern of the standard setting bodies to achieve the comparability of financial statements. Given the NAFTA and the fact that the SEC does not require reconciliation 
of the most important difference between Latin American and US GAAP inflation accounting, it still appears that the SEC could not eliminate or simplify the required reconciliations for Latin American firms filing Form 20-F. These findings suggest that national regulators and standard setters need to work with an aim toward convergence of national GAAP and US GAAP.

\section{References}

Adams, C.A., Weetman, P., and Gray, S. J. "Reconciling National with International Accounting Standards: Lessons from a Study of Finnish Corporate Reports", European Accounting Review, Vol. 2, No. 3, UK, Routledge Journals, Taylor \& Francis Group Ltd, December 1993, pp. 471-494.

Adams, C.A., Weetman, P., Jones, A. E., and Gray, S. J. "Reducing the burden of US GAAP reconciliations by foreign companies listed in the United States: the key question of materiality", European Accounting Review, Vol. 8, No. 1, UK, Routledge Journals, Taylor \& Francis Group Ltd, January 1999, pp. 1-22.

Alford, A., Jones, J., Leftwich, R., and Zmijewski, M. "The Relative Informativeness of Accounting Disclosures in Different Countries", Journal of Accounting Research, Vol. 31, Supplement, Chicago, Institute of Professional Accounting at the Graduate School of Business, 1993, pp. 183-229.

Amir, E., Harris, T., and Venuti, E. "A Comparison of the Value Relevance of US versus non-US GAAP Accounting Measures using Form 20-F Reconciliations", Journal of Accounting Research, Vol. 31, Supplement, Chicago, Institute of Professional Accounting at the Graduate School of Business, 1993, pp. 230-264.

Bandyopadhyay, S. P., Hanna, J. D., and Richardson, G. "Capital markets effects of US-Canada GAAP differences", Journal of Accounting Research, Vol. 32, No. 2, Chicago, Institute of Professional Accounting at the Graduate School of Business, Autumn 1994, pp. 262-277.
Barth, M. E., and Clinch, G. "International accounting differences and their relation to share prices: Evidence from U.K., Australian, and Canadian firms", Contemporary Accounting Research, Vol. 13, No. 1, Canada, Canadian Academic Accounting Association, Spring 1996, pp. 135-170.

Cooke, T.E. "The Impact of Accounting Principles on Profits: The US versus Japan", Accounting and Business Research, Vol. 23, No. 92, UK, The Institute of Chartered Accountants in England and Wales, Autumn 1993, pp. 460-476.

Davis-Friday, P.Y., and Rivera, J.M. " Inflation Accounting and 20-F Disclosures: evidence from Mexico", Accounting Horizons, Vol. 14, No. 2, Florida, American Accounting Association, June 2000, pp. 113-165.

Financial Accounting Standards Board, Canadian Institute of Chartered Accountants and Instituto Mexicano de Contadores Públicos, A.C. Significant Differences in GAAP in Canada, Chile, Mexico and the United States. $4^{\text {a }}$ edición, Canadian Institute of Chartered Accountants, 2002

Fulkerson, C.L., and Meek, G.K. "Analysts Earnings Forecasts and the Value Relevance of 20-F Reconciliations from non-U.S. to U.S. GAAP", Journal of International Financial Management and Accounting, Vol. 9, No. 1, Oxford, Blackwell Publishers, January 1998, pp. 1-14.

Goldberg, S.R., and Godwin, J.H. "Differences between U.S. and Non/U.S. GAAP and the Quality of Earnings", Working Paper, University of Georgia, 1992.

Gray, S. J. "The impact of international accounting differences from a security- 
analysis perspective: some European evidence", Journal of Accounting Research, Vol. 18, No. 1, Chicago, Institute of Professional Accounting at the Graduate School of Business, Spring 1980, pp. 64-76.

Hellman, N. "A comparative analysis of the impact of accounting differences on profits and return on equity. Differences between Swedish practice and US GAAP", European Accounting Review, Vol. 2, No. 3, UK, Routledge Journals, Taylor \& Francis Group Ltd, December 1993, pp. 495-530.

International Accounting Standards Board: SEC Filings by Non-US Companies. A study conducted for the IASB staff by Company Reporting Limited. Second edition, 2001.

Larson, R.K. and Kenny, S.Y. "The harmonization of accounting standards: progress in the 1990s", Multinational Business Review, Vol. 7, $\mathrm{N}^{\circ} 1$, Institute of International Business, Saint Louis University, Spring 1999, pp. 1-12.

Meek, G.K. "U.S. securities market responses to alternative earnings disclosures of nonU.S. multinational corporations", The Accounting Review, Vol. LVIIIs, No. 2, Florida, American Accounting Association, April 1983, pp. 394-402.

Meek, G.K., and Saudagaran, S.M. "A survey of research on financial reporting in a transnational context", Journal of Accounting Literature, Vol. 9, Fischer School of Accounting, University of Florida, 1990, pp. 145-182.

Nobes, C. and Parker, R. Comparative international accounting. London: PrenticeHall, 1998.

Norton, J. "The impact of Accounting Practices on the Measurement of Profit and Equity: Australia versus the United States", Abacus, Vol. 3, No. 3, Sydney, Blackwell Publishers, September 1995, pp. 495-530.

Parker, R.H., and Morris, R.D. "The Influence of U.S. GAAP on the Harmony of Accounting Measurement Policies of Large Companies in the U.K. and Australia", Abacus, Vol. 37, No. 3, Sydney, Blackwell Publishers, October 2001, pp. 297-327.

Rees, L.L. "The information contained in reconciliations to earnings based on US accounting principles by non-US companies", Accounting and Business
Research, Vol. 25, No. 100, UK, The Institute of Chartered Accountants in England and Wales, Autumn 1995, pp. 301310.

Rivera, J.M. "The internationalisation of accounting standards: Past problems and current prospects", The International Journal of Accounting, Vol. 24, $\mathrm{N}^{\circ}$. England, JAI Press Inc, September 1989, pp. 320341.

Rueschhoff, N.G., and Strupeck, D. "Equity Returns: Local GAAP versus US GAAP for Foreign Issuers from Developing Countries", The International Journal of Accounting, Vol. 33, No. 3, England, JAI Press Inc, March 1998, pp. 377-389.

Samuels, J.M. and Piper, A.G. International accounting: A survey. New York: St. Martin's Press, 1985.

Siconolfi, M., and Salwen, M. "Big Board, SEC Fight Over Foreign Stocks", Wall Street Journal, May 13, 1992.

Street, D. L., Gray, S. J. and Bryant, S.M. "Acceptance and Observance of International Accounting Standards: An Empirical Study of Companies Claiming to Comply with IASs", International Journal of Accounting, Vol. 34, N ${ }^{\circ}$ 1, England, JAI Press Inc, January 1999, pp. 11-48.

Street, D.L., Nichols, N.B., and Gray, S.J. "Assessing the Acceptability of International Accounting Standards in the US: An Empirical Study of the Materiality of US GAAP Reconciliations by Non-US Companies Complying with IASC Standards", The International Journal of Accounting, Vol. 35, No. 1, England, JAI Press Inc, January 2000, pp. 27-63.

Street, D. L., and Gray, S. J. "Factors influencing the extent of corporate compliance with International Accounting Standards: Summary of a research monograph", Journal of International Accounting Auditing \& Taxation, Vol. 11, No. 1, Haworth College of Business, Western Michigan University, USA, January 2002, pp. 51-76.

Street, D.L. and Larson, R.K. "Large accounting firms' survey reveals emergence of two standard system in the European union" Advances in International Accounting, Vol. 17, Elsevier , 2004, pp. 1-29. 
Tay, J.S.W., and Parker, R.H. "Measuring international harmonization and standardization", Abacus, Vol. 26, No. 1, Sydney, Blackwell Publishers, March 1990, pp. 71-88.

Vergoosen, R.G.A. "US GAAP and annual reporting by Dutch companies listed in the United States". Paper presented at the International Accounting Research Conference Multinational Enterprises and Global Change, University of Warwick, England. 1996.

Weetman, P., and Gray, S.J. "International financial analysis and comparative accounting performance: the impact of UK versus US accounting principles on earnings", Journal of International Financial Management and Accounting, Vol. 2, No. 2, Oxford, Blackwell Publishers, March 1990, pp. 111-130.

Weetman, P., and Gray, S.J. "A Comparative International Analysis of the Impact of
Accounting Principles on Profits: The USA versus the UK, Sweden and The Netherlands", Accounting and Business Research, Vol. 21, No. 84, UK, The Institute of Chartered Accountants in England and Wales, Autumn 1991, pp. 363-379.

Weetman, P. J., Adams, C.A., and Gray, S.J. "Profit Measurement and UK Accounting Standards: A Case of Increasing Disharmony in Relation to US GAAP AND IASs", Accounting and Business Research, Vol. 28, No. 3, UK, The Institute of Chartered Accountants in England and Wales, Summer 1998, pp. 189-208.

Whittington, M. "Problems in Comparing Financial Performance Across International Boundaries: A Case Study Approach", The International Journal of Accounting, Vol. 35, $\mathrm{n}^{\mathrm{o}} 3$, England, JAI Press Inc, June 2000, pp 399-413. 


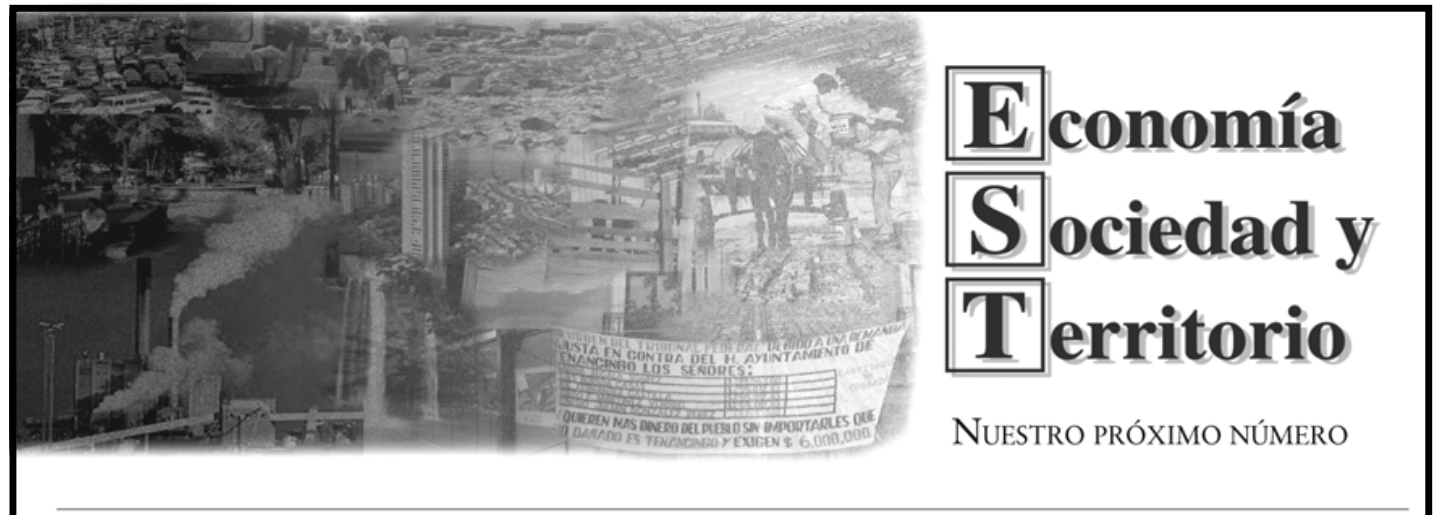

vol. vII, núm. 24, mayo-agosto 2007

\section{Contenido}

- Víctor Ramiro Fernández-Satto y José Ignacio Vigil-Greco

Los clusters, ¿ paradigma de desarrollo territorial para América Latina? "Fallas de origen”, reformulación teórica y desafíos metodológicos

- Ramiro Flores-Xolocotzi y Manuel de Jesús González-Guillén Consideraciones sociales en el diseño y planificación de parques urbanos

- Ovidio González-Gómez y Rossana Nieto-López

Comportamiento logístico de las empresas de manufactura en Querétaro, México

- Rodolfo García-Zamora, Oscar Pérez-Veyna, Guillermo Foladori, Raúl DelgadoWise, Miguel Moctezuma-Longoria, Elivier Reyes-Rivas, Humberto Márquez-Covarrubias, Patricia Rivera-Castañeda.

Paradojas de la migración internacional y el medio ambiente

- Raúl Pacheco-Vega

Construyendo puentes entre la política ambiental y la política de tratamiento de aguas en la cuenca Lerma-Chapala

- Alejandro Macías-Macías

La identidad colectiva en el sur de Jalisco

- Armando Nevárez-Sida, Patricia Constantino-Casas y Fernando García-Contreras Comparación de la eficiencia técnica de los sistemas de salud en países pertenecientes a la Organización Mundial de la Salud

- Fábio Duarte-de Araújo-Silva

La construcción de realidades abstractas: un ensayo sobre la investigación territorial

SUSCRIPCIONES

Suscripción anual (3 números):

México \$240.00 (anual)

Estados Unidos y Canadá Centro y Sudamérica

Otros países
Solicítela a:

El Colegio Mexiquense, A.C.

Departamento de adquisiciones y librería

Apartado postal 48-D

Toluca 50120, México, MÉXICO

Teléfono: (01722) 2180100,2180056

2180358 y 21814 42; Fax: extensión 200

E-mail: adqbib@cmq.edu.mx 